\title{
Spór odnawialnych źródeł energii z atomem
}

\author{
Dispute between Renewable Energy Sources \\ and Nuclear Energy
}

\author{
Władysław Mielczarski \\ Politechnika Łódzka \\ ORCID: https://orcid.org/0000-0001-6670-9678 \\ E-mail: wladyslaw.mielczarski@p.lodz.pl
}

\section{Abstract}

The article contains an analysis of the power balance and the balance of electricity from the point of view of renewable energy sources. The author indicates that renewable energy sources are not fully available, so they can't be included in the power balance. It does not matter to the power balance how much power will be installed in renewable sources. This dispute in this area is settled by the laws of physics and no faith, climate beliefs or even money will change that. Renewable energy sources are put into the energy balance for political reasons. As a result of the priority, dispose power plants are not fully used, which results in the need to subsidize conventional power plants. Such subsidies are also applied in Poland. The "power market" being introduced is PLN 40 billion subsidies, mainly for coal-fired power plants.

Keywords - Renewable energy sources, conventional power plants, power balance, electricity balance 
$\mathrm{Na}$ portalach energetycznych pojawił się wysp artykułów po podobnych tytułach: Cała prawda 0 ..., w których zwolennicy odnawialnych źródeł energii (OZE) czy energetyki jądrowej próbują wykazać wyższość preferowanej technologii. Jest to spór mało użyteczny, ponieważ technologie te działaja w innym obszarze bilansowania systemu elektroenergetycznego.

\section{Bezpieczeństwo energetyczne}

Chociaż definicja bezpieczeństwa energetycznego jest dobrze znana i powszechnie akceptowana, najczęściej wyrażana jako zapewnienie ciągłych dostaw paliw i energii do społeczeństwa i gospodarki, po akceptowanych cenach, to ocena, czy dany system energetyczny można uznać za bezpieczny, nie jest łatwa.

$\mathrm{Na}$ potrzeby systemu elektroenergetycznego za bezpieczny możemy uznać system który spełnia dwa podstawowe kryteria zbilansowania: mocy i energii oraz standardy pracy sieci zapewniając ciągłą dostawę energii elektrycznej- 24 godziny na dobę i 7 dni w tygodniu. Spełnienie tych podstawowych kryteriów zbilansowania mocy i energii jest pokazane na rysunku 1.

Moc zainstalowana w pełni dyspozycyjnych elektrowniach, do jakich należa tylko trzy technologie: węgla, gazu i energii jądrowej, musi być większa niż maksymalne zapotrzebowanie na moc plus odpowiednia rezerwa. Odnawialne źródła energii nie sa w pełni dyspozycyjne, a więc nie moga być wliczane do bilansu mocy. Jasno widać, że elektrownie konwencjonalne: węglowe, gazowe czy jądrowe działają w innym obszarze niż OZE. Nie ma znaczenia dla bilansu mocy, jak dużo mocy zostanie zainstalowane w źródłach odnawialnych. Ten spór w tym obszarze jest rozstrzygnięty przez prawa fizyki i żadna wiara, przekonania klimatyczne czy nawet pieniądze tego nie zmienią.

Bezpieczeństwo energetyczne wymaga również spełnienia bilansu energii elektrycznej. Do tego bilansu można wliczyć odnawialne źródła, ale nie jest to konieczne. Jeżeli dyspozycyjne elektrownie (węgiel, gaz i atom) spełniają kryteria bilansu mocy, to również automatycznie spełnią bilans energii. Jednak ze względów politycznych (polityka klimatyczna) do bilansu energii wprowadza się OZE, którym dodatkowo nadaje się priorytet pracy. Powoduje to pewne problemy ekonomiczne, ponieważ na skutek priorytetu OZE elektrownie dyspozycyjne nie są w pełni wykorzystane, co skutkuje koniecznością subsydiowania elektrowni konwencjonalnych. Takie subsydia stosuję się również 
w Polsce. Wprowadzany właśnie „rynek mocy” to 40 mld zł subsydiów, głównie dla elektrowni węglowych.

\section{Bezpieczeństwo energetyczne to:}

\section{Bilans mocy i Bilans energii}

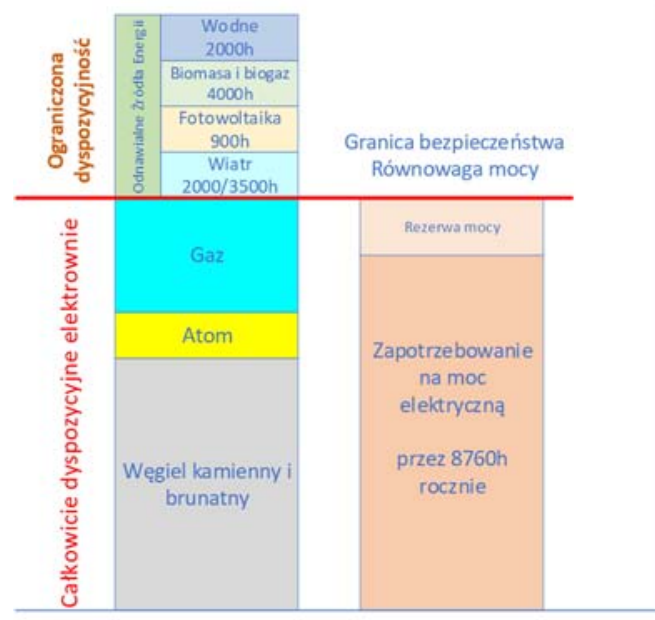

Zdolności produkcyjne - Zainstalowane

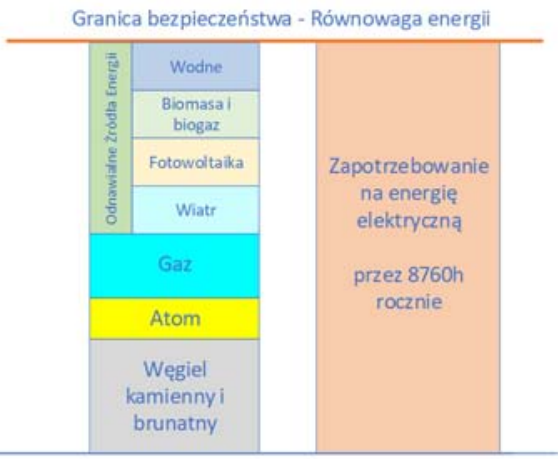

Zdolności produkcyjne - Wykorzystane

Rysunek 1. Bilans mocy i energii elektrycznej

Źródło: opracowanie własne.

\section{Aspekt energetyczny}

W systemie rynkowym technologie, które są tańsze, wypierają te, które są bardziej kosztowne. Jednakże muszą być spełnione dwa dodatkowe warunki: produkt musi być łatwo magazynowany oraz musi istnieć możliwość transportu produktu na duże odległości.

Przesył energii elektrycznej w systemie prądu przemiennego jest bardzo trudny na odległości większe niż $300 \mathrm{~km}$ i dodatkowo energia elektryczna rozpływa się zgodnie z prawami fizyki (prawa Kirchhoffa), a nie wolą dyspozytora. Energii elektrycznej nie można magazynować w jej pierwotnej formie, a formy pośrednie (energia chemiczna czy potencjalna) są mało efektywne. Zbudowanie magazynu energii, nawet w formie 
pośredniej, który działałby dłużej niż 3-4 godziny, jest bardzo trudne, a przecież energia elektryczna ma być dostarczana 24 godziny na dobę i 7 dni w tygodniu.

Nie ma więc decydującego znaczenia w systemie energii elektrycznej, że dane źródło jest tańsze, jeżeli nie jest w pełni dyspozycyjne. Mówiąc językiem sportowym, bilans mocy i energii to dwie różne dyscypliny, z tym, że elektrownie konwencjonalne, jako w pełni dyspozycyjne, mogą startować w obu dyscyplinach, a źródła odnawialne tylko w jednej. Spór OZE $z$ atomem jest w zasadzie sporem odnawialnych źródeł z technologiami konwencjonalnymi i jest sporem pozornym, ponieważ cechy tych technologii sa zupełne różne.

Odnawialne źródła energii nie mogą startować w dyscyplinie „bilans mocy”, a startują w dyscyplinie „,bilans energii” tylko dlatego, że „sędzia” (Unia Europejska) stworzyła dla OZE specjalne preferujące reguły. To tak jakby w sporcie - w biegu na pewnym dystansie - jedni zawodnicy musieli przebiec pełen dystans, a drudzy - ci preferowani tylko 20-30\% dystansu. Dlatego nie ma znaczenia, jaki będzie koszt produkcji energii z OZE i elektrowni konwencjonalnych. Tu nie ma i nie będzie konkurencji.

Można zadać pytanie: co będzie, jeżeli odnawialne źródła energii będą w stanie produkować energię elektryczna po, np. 100zł/MWh, podczas gdy elektrownie konwencjonalne po 400zł/MWh? Technicznie nic się nie zmieni. Dalej elektrownie konwencjonalne będą musiały zaspokoić zapotrzebowanie na moc wraz z odpowiednim marginesem rezerwy. Tylko subsydia dla elektrowni konwencjonalnych, co obecnie warunkach polskich oznacza subsydia dla węgla, będą większe. Koszty produkcji energii ze źródeł odnawialnych nie mają wpływu na bilans mocy. Spór, czy energia ze źródeł odnawialnych jest tańsza, czy droższa od energii z elektrowni konwencjonalnych, jest bezproduktywny. Technologie mogą ze sobą konkurować, o ile mają takie same cechy techniczne, czyli jest możliwa konkurencja pomiędzy elektrowniami węglowymi, gazowymi czy jądrowymi, ale OZE do tej konkurencji nie kwalifikuje się ze względu na inne cechy techniczne.

\section{Polityka energetyczna 2040}

Na tle zasad zapewnienia bezpieczeństwa energetycznego można zastanawiać się, czy proponowana przez Ministerstwo Energii polityka energetyczna do roku 2040 [1;2] 
spełnia przedstawiane kryteria zbilansowania mocy i energii elektrycznej. Analiza pokazuje, że pomimo wielu radykalnych propozycji, takich jak rezygnacja z węgla brunatnego czy budowa elektrowni jądrowych, oraz znaczny rozwój morskiej energetyki wiatrowej przedstawiona propozycja spełnia zasady zapewnienia bezpieczeństwa energetycznego w zakresie produkcji energii elektrycznej - rysunek 2.

\section{Polityka energetyczna 2040}

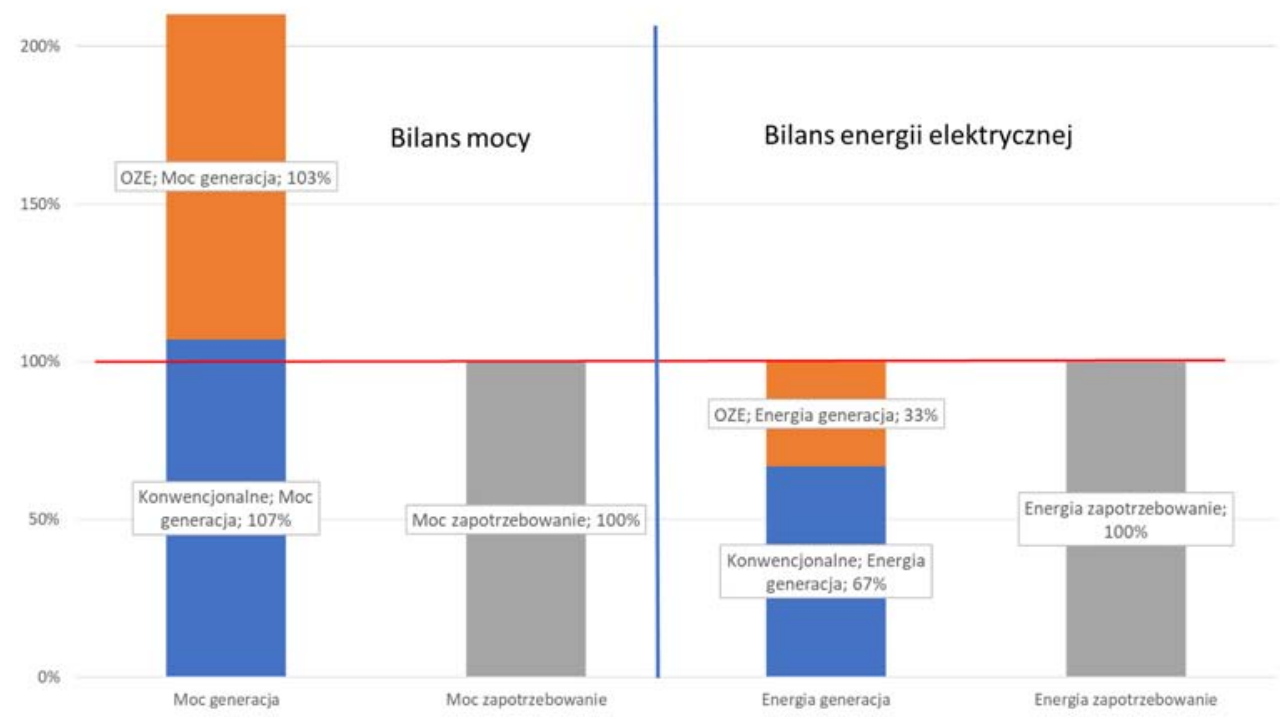

Rysunek 2. Bilans mocy i energii w Polityce energetycznej 2040

Źródło: opracowanie własne.

Moce zainstalowane w konwencjonalnych elektrowniach pokrywają zapotrzebowania na moc wraz z 7\% rezerwą mocy. Dodatkowo przewiduje się, że moce zainstalowane w odnawialnych źródłach energii będą wynosić około 103\% zapotrzebowania na moc. Produkcja energii elektrycznej ze źródeł odnawialnych powinna wynieść około 33\% całkowitego zapotrzebowania, podczas gdy z elektrowni konwencjonalnych tylko $67 \%$.

Tak niski poziom produkcji z elektrowni konwencjonalnych będzie powodował konieczności ich subsydiowania. Potrzebne będą kolejne „rynki mocy” - subsydia dla energetyki, głównie węglowej, wynikające z obowiązków udziału energii ze źródeł odnawialnych. 


\section{Bibliografia}

[1] Ministerstwo Energii (2018a), POLITYKA ENERGETYCZNA POLSKI DO 2040 ROKU (PEP2040), https://www.gov.pl/documents/33372/436746/PEP 2040_projekt_v12_2018-11-23.pdf/ee3374f4-10c3-5ad8-1843-f58dae119936

[2] Ministerstwo Energii (2018b), Polityka energetyczna Polski do 2040 r. Zapraszamy do konsultacji, https://www.gov.pl/web/energia/polityka-energetyczna-polski-do-2 040-r-zapraszamy-do-konsultacji 